Published in final edited form as:

J Comp Neurol. 2010 February 15; 518(4): 405-422. doi:10.1002/cne.22248.

\title{
Patterned assembly and neurogenesis in the chick dorsal root ganglion
}

\author{
Lynn George ${ }^{1}$, Jennifer Kasemeier-Kulesa ${ }^{1}$, Branden R. Nelson ${ }^{1}$, Naoko Koyano- \\ Nakagawa $^{2}$, and Frances Lefcort ${ }^{1}$ \\ ${ }^{1}$ Department of Cell Biology and Neuroscience, Montana State University. \\ 2 Department of Neuroscience (past), Stem Cell Institute (current), and Lillehei Heart Institute \\ (current) University of Minnesota.
}

\section{Abstract}

The birth of small-diameter TrkA+ neurons that mediate pain and thermo reception begins approximately 24 hours after the cessation of neural crest cell migration from progenitors residing in the nascent dorsal root ganglion. Although multiple geographically distinct progenitor pools have been proposed, this study is the first to comprehensively characterize the derivation of small diameter neurons. In the developing chick embryo, we identify novel patterns in neural crest cell migration and colonization that sculpt the incipient ganglion into a post-mitotic neuronal core encapsulated by a layer of proliferative progenitor cells. Furthermore, we show that this outer progenitor layer is composed of three spatially, temporally, and molecularly distinct progenitor zones, two of which give rise to distinct populations of TrkA+ neurons.

\section{Keywords}

dorsal root ganglion; neurogenesis; Pax3; TrkA; neural crest

\section{Introduction}

The mature dorsal root ganglion (DRG) is composed of approximately 20 different subpopulations of sensory neurons in addition to glial cells (Scott, 1992). These neuronal subtypes are distinct in their choice of peripheral and central targets and neurotrophin dependency, in addition to their function. How does such a diverse group of cells derive from a common pool of precursor cells, the neural crest? In the past few years several studies have identified transcription factors that are differentially expressed by distinct subsets of sensory neurons (Arber et al., 2000; Chen et al., 2006; Hippenmeyer et al., 2005; Kramer et al., 2006; Levanon et al., 2002; Lin et al., 1998; Ma et al., 1999; Montelius et al., 2007; Nakamura et al., 2008; Zhong et al., 2006). In spite of these advances, our understanding of the cellular mechanisms and lineal relationships that sculpt the emergence and assembly of the DRG remains fragmentary.

Within the developing DRG, sensory neurons are generated in two temporally distinct but overlapping waves according to their size and sensory modalities (Carr and Simpson, 1978). Large-diameter, TrkC+ and TrkB+ neurons that mediate transmission of proprioceptive and mechanoceptive information (respectively), are generated first, beginning in the chick at Hamburger/Hamilton Stage (St.) (Hamburger and Hamilton, 1992) 16 and 19 (respectively) (Rifkin et al., 2000). Small diameter, TrkA+ afferents that mediate pain and temperature sensation are primarily born during the second wave of neurogenesis that begins at St.25 and persists for the next 48 hours (Carr and Simpson, 1978; Rifkin et al., 2000). Initially, TrkA+ neurons are dispersed throughout the DRG, but within three days they become confined to 
the dorsomedial (DM) $2 / 3$ of the ganglion (Rifkin et al., 2000). Within the mature DRG, the TrkA+ population constitutes more than $70 \%$ of the total neuron number and is comprised of numerous subtypes of neurons including heat, cold, and pain sensors (Patapoutian, 2001; Patapoutian et al., 2003). The development of all DRG neurons is dependent on the expression of the basic helix-loop-helix transcription factor genes Neurogenin (Ngn) 1 or 2 , (Ma et al., 1999).

The birth of second wave neurons begins approximately 24 hours after the cessation of neural crest cell (NCC) migration and to date the lineage of this wave remains speculative. The first candidate progenitor pool for small diameter, DM neurons was proposed by Victor Hamburger in 1981 and designated the inner and outer marginal zone (IOMZ), a band of densely packed cells along the medial and dorsolateral (DL) perimeter of the ganglion appearing at stage 25 (Hamburger et al., 1981). Numerous other spatially discrete progenitors pools have since been proposed including Ngn1+ cells in the DRG perimeter (Perez et al., 1999), mitotically active cells in the DRG interior (Rifkin et al., 2000), boundary cap cells in the dorsal root (Maro et al., 2004), and migratory neuroepithelial cells in the spinal cord (Sharma et al., 1995). Thus a major goal of this study was to definitively determine the derivation of cells born during the second wave of neurogenesis.

Recent work shows that sensory specific NCCs comprise two subsets based on their propensity to cross the dorsal midline (George et al., 2007). Those that exclusively migrate ipsilaterally colonize the DRG core and generate neurons during the first wave of neurogenesis. NCCs within the second subset migrate either ipsilaterally or contralaterally and specifically target the DRG perimeter where they postpone differentiation and later give rise to TrkA+ neurons during the second wave (George et al., 2007). In the work reported here we demonstrate the patterned morphogenesis of migrating NCCs into a differentiated neuronal core encapsulated by a proliferative layer of progenitors. We show that this proliferative capsule is molecularly heterogeneous and is assembled in a step-wise fashion with NCCs colonizing different regions during sequential developmental time points. By birth dating studies and lineage analyses we show that TrkA+ neurons derive from two temporally, spatially, and molecularly distinct progenitor pools within this perimeter. Thus, this study identifies novel assembly patterns and molecularly heterogeneous classes of progenitor cells that together orchestrate the emergence of the DRG.

\section{Materials and Methods}

\section{Embryos}

Fertilized White Leghorn chicken eggs were obtained from Charles River Laboratories and incubated at $37^{\circ} \mathrm{C}$. All embryos were staged according to Hamburger and Hamilton (Hamburger and Hamilton, 1992), and fixed in 4\% paraformaldehyde in 1X phosphate buffered saline, $\mathrm{pH}$ 7.4.

\section{In ovo injections and transfections}

The EGFP expression plasmid, pCAX, was used for all EGFP electroporations (Osumi and Inoue, 2001). All plasmids were injected at a concentration of $0.25 \mu \mathrm{g} / \mu \mathrm{l}$ in phosphatebuffered saline using a pulled capillary glass needle (World Precision Instruments, TW100F4) and Picospritzer III (Parker Instrumentation) until the entire length of the neural tube was filled (Muramatsu et al., 1997). Electroporator settings were 5 pulses and $23 \mathrm{~V}$ with an interval of $100 \mathrm{~ms}$. The EGFP retrovirus $\left(5 \times 10^{8}\right.$ to $2 \times 10^{9}$ virions $/ \mathrm{ml}$ ) (Okada et al., 1999) and the RFP plasmid (Teddy et al., 2005) were kindly provided by Dr. Rusty Lansford (Caltech). For BrdU injections, eggs were windowed and injected with $50 \mu \mathrm{g}$ BrdU per egg onto the chorioallantoic membrane. Unless otherwise stated, BrdU injected eggs were 
incubated for three hours before embryo removal and fixation. Transverse sections from the trunk axial level only (between the wing bud and hind limb) were used for BrdU counts.

\section{Immunohistochemistry (IHC)}

All washing, blocking, secondary antibody, and post-fixation steps were performed at room temperature. All other steps were performed at $4^{\circ} \mathrm{C}$ unless stated otherwise. Embryos were fixed in 4\% paraformaldehyde/PBS from 1 to 5 hours (depending on the age), rinsed in PBS, cryoprotected through a series of sucrose solutions in PBS $(5 \%, 15 \%, 30 \%)$, incubated for 2 hours in a 1:1 mixture of $30 \%$ sucrose and optimal cutting temperature (OCT) compound (Tissue-Tek), followed by 2 hours in OCT. Embryos were then frozen and cryosectioned at $16 \mu \mathrm{m}$. For antibody staining, slides were bathed in PBS for 20 minutes, followed by NGS block (10\% normal goat serum, $1 \%$ glycine, $0.4 \%$ Triton X-100 in $30 \mathrm{mM}$ Tris, $150 \mathrm{mM}$ $\mathrm{NaCl}$ ) for 1 hour, and overnight incubation in primary antibody (in NGS block). Slides were then rinsed in NGS block, incubated in Alexa Fluor secondary antibody (1:2000 in NGS block) for 1 hour, rinsed in 3:1 tris buffered saline: NGS block, and mounted in Prolong Antifade (Invitrogen.) For double IHC with BrdU, the same procedure as above was used through the application of secondary antibody. Following this step, slides were washed in PBS, post-fixed in $4 \%$ paraformaldehyde for 10 minutes, washed in PBS, incubated in $0.5 \mathrm{~N}$ $\mathrm{HCl}$ at $55^{\circ} \mathrm{C}$ for 6 minutes, post-fixed for 10 minutes, washed again in PBS, incubated in 0.5 $\mu \mathrm{g} / \mathrm{ml}$ proteinase $\mathrm{K}$ at $37^{\circ} \mathrm{C}$ for 4 minutes, post-fixed for 15 minutes, washed in PBS, blocked in NGS, incubated in anti-BrdU primary antibody in NGS overnight, washed in PBS, incubated in secondary antibody for 1 hour, washed again and mounted in Prolong Antifade.

\section{Antibody Characterization}

Tuj-1 monoclonal antibody (MAb) is a pan-neuronal marker that specifically recognizes neuronal Class III $\beta$-tubulin. It labels all neurons, and not glia, in central and peripheral nervous tissue. Three independent methods demonstrate that Tuj-1 binds specifically to the C-terminus of the $\beta$ III isoform (Lee et al., 1990): 1) Immunoblots run on $\beta$-tubulin extracts and a $48 \mathrm{kDa} \beta$-tubulin polypeptide lacking the $\mathrm{C}$-terminus domain, Tuj1 reacted only with the unproteolyzed form; 2 ) $\beta I I I$ is the only $\beta$-tubulin isotype resistant to sulfhydryl crosslinking and migrates through an SDS-PAGE gel more slowly than crosslinked forms. In immunoblots, Tuj 1 antibody reacts exclusively with uncrosslinked $\beta$-tubulin; 3) On Western blots of bacterial fusion proteins containing the $\mathrm{C}$-terminal regions of chicken class II, III, IV, V and human class I, II, III, IV, and V $\beta$-tubulin, Tuj1 exclusively reacts with fusion proteins containing the $\mathrm{C}$-terminal sequences of $\beta$ III.

On Western blots BEN MAb recognizes two molecular forms with different molecular weights according to the tissue type: in the spinal cord, sympathetic ganglia, and DRG, a 95 $\mathrm{kDa}$ form is identified, while in the bursa of Fabricius and bone marrow the immunoreactive band corresponds to $100 \mathrm{kDa}$ (Pourquie et al., 1990). In vitro cultures of DRG and sympathetic ganglia show that the cell surface glycoprotein BEN is transiently expressed on neurons and first appears just after withdrawal from the cell cycle. BEN immunoreactivity disappears from the DRG by St.36/E10 (Pourquie et al., 1990).

The GTP binding protein gene, RhoB, is expressed in the dorsal neural tube and on migrating NCCs during St. 10 to 20. Specificity of the RhoB antibody was established by Western blot analysis of bacterial lysate of RhoB, RhoA, Rac1 and Cdc42 fusion proteins. The antibody recognizes a single band of approximately $35 \mathrm{kDa}$, and the pattern of chick RhoB protein, as observed via IHC, is also identical to mRNA expression viewed by in situ hybridization (Liu and Jessell, 1998). 
The Sox 10 antiserum was affinity-purified and preadsorbed on powder of Sox10-deficient embryos (Stolt et al., 2003). The antibody stains neural and glial progenitor cells, and does not cross-react with the related Sox8 or Sox9 (Maka et al., 2005).

Specificity of the anti-BrdU antibody was tested by enzyme-linked immunosorbent assay (ELISA) and flow cytometry. In addition, in control experiments where BrdU was omitted, no staining was observed (Gratzner, 1982; Meyer et al., 1989).

On Western blots of E3 chick neural tube and notochord extract, the Pax3 antibody stains a single band of approximately $60 \mathrm{kDa}$ (Venters et al., 2004). In addition, the expression of Pax3 protein is similar to that of previously reported Pax3 mRNA (Baker et al., 1999; Stark et al., 1997).

Neurofilament antiserum specifically labels the 70kDa neurofilament polypeptide (NF70) in immunoautoradiography assays on two-dimensional gels of either whole brain or spinal cord neurofilament fractions (Granger and Lazarides, 1983).

The Ngn2 pattern of antibody staining is identical to that seen with other anti-Ngn2 antibodies (Zhou et al., 2001), and matches the chick ngn 2 mRNA expression pattern seen by in situ hybridization (Novitch et al., 2001).

The TrkA antibody was developed by Frances Lefcort in 1994 in Dr. Louis Reichardt's laboratory (UCSF). Two antisera were generated that gave identical staining patterns in chick embryos and matched the trkA mRNA expression pattern in published in situ hybridizations (Schropel et al., 1995). In Western blots the antibody recognizes a single band of approximately $145 \mathrm{kDa}$. This antibody has been used as a bona fide marker for TrkA in the major chick labs that study TrkA function (Gallo et al., 1997; Karlsson et al., 1998; Oakley et al., 1997; Rifkin et al., 2000; Schropel et al., 1995; v Holst et al., 1997).

\section{Positions of ipsilaterally and contralaterally migrating NCCs}

HNK-1 immunolabeling was used to identify the DRG perimeter. The dorsal and ventral poles were outlined as follows: the respective ventral and dorsal boundaries were determined by locating the most interior HNK-1+ cell within the pole and drawing a boundary line perpendicular to the dorsal/ventral axis of the DRG along the interior border of that cell. Remaining perimeter regions were designated as either medial or lateral. All regions interior to the HNK-1+ perimeter and poles were designated as core.

\section{Cell Counts}

For quantification of EGFP+ ipsilateral versus contralateral cells and EGFP+/Ngn2+ cells, embryos were serially sectioned on the transverse plane at $16 \mu \mathrm{m}$. All EGFP+ objects with a diameter of $5 \mu \mathrm{m}$ or larger were counted. To determine the percentage of EGFP+ ipsilateral versus contralateral NCCs within specific geographic regions of the DRG, the center three sections of two ganglia were counted per axial level including the wing (brachial), the hind limb, and the region intervening these two levels (trunk). Counts were restricted to center sections to ensure that all geographic regions of interest, including the dorsal and ventral poles, the medial and lateral perimeter, and the DRG core were present in each section. To determine the percentage of ipsilateral versus contralateral cells that were $\mathrm{Ngn} 2+$, all EGFP+ cells within the trunk were counted. For both data sets the Abercrombie correction factor (Abercrombie, 1946; Guillery, 2002) was used to correct for overcounting (average cell diameter $(\mathrm{h})=10 \mu \mathrm{m})$. Counts represent the mean number of cells \pm the standard deviation; statistical significance was determined by an unpaired Student's t-test. 


\section{Cell migration and lineage tracing in slice explants with Dil and fluorescent micro-beads}

Transverse slices from the trunk of E4/St.23/24 embryos (Krull and Kulesa, 1998) were transferred to Millicell-CM $0.4 \mathrm{~mm}$ culture plate inserts (Millipore) saturated in neurobasal media (Invitrogen) supplemented with B27 (Invitrogen). A DiI (Invitrogen D282) solution (made from a $0.5 \%$ stock solution in $100 \%$ ethanol diluted $1: 10$ in warmed $\left(38^{\circ} \mathrm{C}\right) 0.3 \mathrm{M}$ sucrose) was loaded into a glass capillary needle and focally injected using a mouth pipette. Images were taken prior to and after a 24-hour culture (Krull and Kulesa, 1998). To label progenitor cells with fluorescent micro-beads, $0.5 \mu \mathrm{m}$ yellow-green fluorescent micro spheres (Molecular Probes) were injected into transverse slice explants using a glass capillary needle and Picospritzer III (Parker Instrumentation).

\section{Reporter Constructs}

The Hes 1 reporter (pHes1-d2EGFP) utilizes the mouse Hes 1 promoter sequence and was a gift from Dr. Ryoichiro Kageyama (Kyoto University) (Ohtsuka et al., 2006). To construct the NeuroM reporter plasmid, the $3 \mathrm{~kb}$ upstream region of the mouse NeuroM homolog, Ath3, including $200 \mathrm{bp}$ of the first exon, was amplified from mouse genomic DNA using sense: GATGTCGACATCTAACAATGTTGCCATT and antisense:

CCTGGATCCCGGGATCAGCTCC primers. The product was digested and cloned into the BamHI and the SalI sites of the pd2EGFP-1 vector (Beckton Dickenson).

\section{In situ hybridization}

In situ using chick NeuroM DIG-labeled riboprobe (Perez et al., 1999; Roztocil et al., 1997) on paraffin sections was performed as described (Nelson et al., 2002; Nelson and Reh, 2008). Briefly, chick embryos were incubated to St. 30, collected, head and viscera were removed and trunks fixed in a modified Carnoy's Solution $(60 \% \mathrm{EtOH} / 30 \%$ formaldehyde/ $10 \%$ Acetic Acid by volume) from stock solutions (100\% EtOH/37\% formaldehyde/100\% Acetic Acid, respectively) overnight at $4^{\circ} \mathrm{C}$. Embryos were rinsed in $70 \% \mathrm{EtOH}$, dehydrated through an $\mathrm{EtOH}$ series to $100 \%$, transferred through xylene, embedded in paraffin, and sectioned at $6-8 \mu \mathrm{m}$. Slides were baked at $68-70^{\circ} \mathrm{C}$ for at least 2 hours, dewaxed in xylene, washed in $100 \% \mathrm{EtOH}$ and air-dried. DIG-labeled probe was diluted in hybridization buffer (50\% deionized formamide/10\% dextran sulfate from 50\% stock/1X Denhardt`s from 50X stock/ $2 \%$ Roche blocking reagent (Roche)/ $0.05 \%$ Tween $20 / 1 \mathrm{mg} / \mathrm{ml}$ yeast tRNA/1X salt solution from 10X stock [2M NaCl, 0.089M Tris $\mathrm{HCl}, 0.011 \mathrm{M}$ Tris base, $0.05 \mathrm{M}$ $\mathrm{NaH}_{2} \mathrm{PO}_{4} \cdot \mathrm{H}_{2} \mathrm{O}, 0.05 \mathrm{M} \mathrm{NaHPO}_{4}, 0.05 \mathrm{M}$ EDTA, pH 7.5, in RNase-free $\mathrm{H}_{2} \mathrm{O}$ ], and incubated under an RNase-free coverslip overnight at $68-70^{\circ} \mathrm{C}$ in a chamber humidified with $50 \%$ formamide $/ 50 \% 2 \mathrm{X} \mathrm{SSC}$. The next day, slides were washed $90 \mathrm{~min}$ in $300 \mathrm{ml}$ of wash solution with $0.1 \%$ Tween at $68-70^{\circ} \mathrm{C}, 30 \mathrm{~min} \mathrm{X} 2$ times in $300 \mathrm{ml}$ of $2 \mathrm{xSSC}$ with $0.1 \%$ Tween at $68-70^{\circ} \mathrm{C}, 10 \mathrm{~min} \mathrm{X} 3$ times in TBS-Tween $(0.1 \%)$ at room temperature, blocked for 30-60 min in a humid chamber with $2 \%$ Roche Blocking Reagent $+10 \%$ serum (FBS or BSA block) in TBS-Tween (500 $\mathrm{l}$ / each slide), and incubated overnight at room temperature with 1/2000 dilution of anti DIG-AP (Roche) in blocking solution. The next day, slides were washed $3 \mathrm{X}$ in TBS containing $0.2 \%$ nonfat milk and $0.1 \%$ Tween with agitation at room temperature, equilibrated with 3 washes in NTMT [0.1M NaCl, $0.1 \mathrm{M}$ Tris pH 9.5, $5 \mathrm{mM}$ $\mathrm{MgCl} 2,0.1 \%$ Tween-20], reacted in NBT/BCIP solution (Sigma) until developed, post-fixed in $4 \%$ paraformaldehyde, washed in TBS, and mounted in Fluoromount $\mathrm{G}$ (SouthernBiotech).

\section{Ablations}

Ablations were performed using a UV-pulsed laser microbeam on a Zeiss/PALM Laser Dissecting Microscope. $200 \mu \mathrm{m}$ transverse slices (Krull and Kulesa, 1998) were placed on $1 \mathrm{~mm}$ thick glass slides on ice and kept hydrated in neurobasal medium. The tissue region 
selected for ablation was first outlined with the laser and then ablated by scanning the region with 15 laser passes per linear inch of tissue on the PALM monitor. Laser settings included an energy of $85-95 \%$, and a focus between 75 and 85 . Following ablation, slices were cultured for 24 hours.

\section{Imaging}

All fluorescent images were captured using an inverted laser scanning confocal microscope (Olympus FV300) with $488 \mathrm{~nm}, 543 \mathrm{~nm}$, and $633 \mathrm{~nm}$ laser lines and Fluoview Software v 5.0. Objectives included a 20X Plan Apo (NA = 0.70) dry objective and a 60X Plan Apo (NA $=1.4$ ) oil immersion lens (Olympus). All transverse sections were $16 \mu \mathrm{m}$ unless otherwise stated. For time-lapse imaging, transverse slices were transferred to culture plate inserts as above. The Millicell membrane with slice preparation was then cut from the plastic insert and placed in a $35 \mathrm{~mm}$ glass bottom dish (MatTek Corporation). Images were captured every 10 minutes using the 20X objective on our FV300 within a heated enclosure. Photomicrographs were assembled in PowerPoint X for Mac and converted to TIFF files using Adobe Photoshop CS4. Magenta-green versions of the Figures were also generated in Photoshop.

\section{Results}

In all results sections the terms dorsomedial (DM) and ventrolateral (VL) indicate position within the DRG (Fig. 1A) and do not necessarily indicate neuronal size or birth date as in previous publications (Hamburger and Levi-Montalcini, 1949).

\section{Formation of the early DRG cytoarchitecture}

Previous work shows that a small number of differentiated neurons are present at the site of the prospective DRG as early as E2.5/ St.15/16 (Rifkin et al., 2000). This finding conflicts with studies suggesting that trunk NCCs migrating prior to St.18 exclusively colonize derivatives ventral to the incipient DRG (Serbedzija et al., 1989). To re-examine this timing, cross-sections were immunolabeled with the pan-neuronal marker Tuj-1, and BEN, a cell surface glycoprotein that is transiently expressed on neurons and appears immediately following withdrawal from the cell cycle. A small number of immunoreactive cells confirmed the presence of differentiated neurons in the St.15/16 DRG (Fig. 1B). Since Ngn2, a basic-helix-loop-helix (bHLH) transcription factor, regulates the first wave of neurogenesis, we examined the expression of $\mathrm{Ngn} 2$ at this same time point. A limited number of NCCs were clearly Ngn2+ at St.15/16 (Fig. 1C).

By E3.5/St 21/22 and continuing through E5/St.27, the developing DRG consists of a neuronal core encapsulated by a proliferative layer of undifferentiated progenitor cells (Fig. 1D, 2A,F,K). We posited that the first neurons born in the DRG play a role in early condensation of the ganglion by forming a seed or nucleus around which later migrating NCCs and differentiating neurons coalesce (Ma et al., 1999;Montelius et al., 2007). To test this hypothesis, successive waves of emigrating NCCs were labeled with different fluorescent proteins. Embryos were first electroporated with an RFP plasmid (Teddy et al., 2005 ) at St.12/13 thereby labeling all waves of migrating NCCs. At St.17/18, these same embryos were injected with an EGFP retrovirus (Okada et al., 1999) to exclusively label late-migrating NCCs. Double injected embryos were harvested at St.20/21, a time point following the arrival of late-migrating NCCs to the DRG, but prior to their differentiation (George et al., 2007). Immunolabeling with Tuj-1 shows the presence of differentiated neurons in the core of the ganglion with the majority co-expressing RFP (in the absence of EGFP), indicating that they derived from the earliest NCCs to colonize the DRG (Fig. 1E, arrows). In contrast, late-migrating NCCs (those expressing either EGFP alone or both RFP 
and EGFP, see Fig. 1 legend) rarely expressed neuronal markers and were primarily found along the margin of the developing ganglion (Fig. 1E, arrowheads).

We next sought to characterize the development of the proliferative layer that encapsulates the DRG from approximately St.21 onward. Our previous electroporation studies showed that contralaterally migrating NCCs specifically colonize the exterior of the DRG (George et al., 2007). Electroporation transfects the neural tube unilaterally and most labeled NCCs migrate within this "ipsilateral" hemisphere. However, a subset of NCCs consistently crosses the midline and migrates within the "contralateral" hemisphere (George et al, 2007). To more comprehensively characterize the behavior and colonization pattern of the contralaterally vs. ipsilaterally migrating subsets, embryos were electroporated with an EGFP plasmid at St.12/13 and harvested at three successive time points. At E3.5/St.21/22, an average of $17.0( \pm 1.2)$ EGFP+ cells (80.5\% of the total number of EGFP+ cells) were present in the ipsilateral DRG per section, while $4.1( \pm 1.3)$ EGFP+ cells $(19.5 \%$ of the total number of EGFP+ cells) were present in the contralateral DRG per section ( $\mathrm{n}=3$ embryos). In the ipsilateral ganglion the highest fraction of EGFP+ cells was located in the DRG core, followed by the dorsal pole and lateral perimeter (Fig. 1F,G). In contrast, in the contralateral ganglion the highest fractions were located in the lateral perimeter and dorsal pole, with relatively few cells in the DRG core (Fig. 1H,I). HNK-1 immunolabeling also showed an obvious medial vs. lateral asymmetry at this stage with the majority of HNK-1+ cells located along the lateral perimeter (Fig. 1D, arrow). No significant difference in these averages was observed at different axial levels including that of the wing bud, trunk, and hind limb (data not shown). At E4.5/St.25, more contralateral EGFP+ cells were present in the medial perimeter and DRG core, although a bias toward the lateral margin was still apparent (not shown). At this time point the ipsilateral ganglion was filled throughout with EGFP+ cells (not shown). At E5/St.27 a new colonization pattern was present in the contralateral DRG with EGFP+ cells now abundant along the DM perimeter as well as in the DRG core. In thick, $80 \mu \mathrm{m}$ cryosections all regions of the contralateral ganglion were colonized with EGFP+ cells, including dense colonization of the medial perimeter (Fig. 1J, arrow). These data show that contralaterally migrating NCCs first accumulate along the lateral perimeter and within the dorsal pole of the DRG, and later heavily colonize the medial perimeter. Since the medial colonization occurs more than 24 hours after the cessation of NCC migration, it likely results from the proliferation of progenitor cells within the DRG dorsal root and/or pole.

Contralaterally migrating NCCs delaminate immediately adjacent to the dorsal apex of the roof plate (Fig. 1K, arrow; George et al., 2007), an expected pattern given that they later cross the dorsal midline. In contrast, Ngn2+ NCCs are located at more VL positions, relatively distant from the dorsal midline, both before (Fig. 1L,M, arrows) and after (Fig. $1 \mathrm{M}$, arrowhead) they exit the neural tube. Based on these cellular positions we asked whether the Ngn2 antigen marks the subset of migrating NCCs that exclusively migrates ipsilaterally (George et al., 2007). To this end, embryos were electroporated with the EGFP plasmid pCAX at St. 12/13, harvested at St.16/17, and immunolabeled for Ngn2. Within the ipsilateral hemisphere, $26.2 \%( \pm 5.2)$ of EGFP+ cells were $\operatorname{Ngn} 2+(\mathrm{n}=3$ embryos; 173 cells $)$ while only $4.3 \%( \pm 0.9)$ of contralateral EGFP+ cells were Ngn2+ (Fig. 1L; $n=3$ embryos; 99 cells; $p$ value $=0.002$ ), confirming that early Ngn $2+$ NCCs predominantly migrate ipsilaterally. The staining pattern of RhoB, a GTPase expressed by premigratory and earlymigrating NCCs (Liu and Jessell, 1998), provides further support for molecular heterogeneity amongst NCCs delaminating from different positions along the dorsal ventral axis of the neural tube, and between ipsilaterally vs. contralaterally migrating NCCs. While RhoB is robustly expressed by premigratory NCCs along the dorsal midline and early migrating NCCs in dorsal positions (Fig. 1M) (Liu and Jessell, 1998), Ngn2 is expressed only at more VL positions (Fig. 1C,L,M). These data provide a mechanistic explanation for 
the bias of contralaterally migrating NCCs to the DRG lateral perimeter and dorsal pole: the more DM delamination of contralaterally-migrating NCCs positions them laterally to delaminating Ngn2+ NCCs as these two cohorts migrate ventrally around the DL margin of the neural tube. Thus, Ngn2+ NCCs delaminate within, or medially, to a stream of ventrally migrating Ngn2- NCCs that exited the neural tube at its dorsal apex (Fig. 1C). The above data demonstrate that trunk NCCs migrating prior to St.18 give rise to the first neurons in the DRG and that these neurons form the innermost core of the ganglion. In addition, they identify geographically distinct zones within the premigratory crest and key events that orchestrate the segregation of post-mitotic neurons to the DRG core and undifferentiated progenitor cells to the DRG perimeter.

\section{The DRG perimeter is a dynamic zone of proliferating progenitor cells}

At St.25 mitotically active cells are primarily located along the perimeter of the DRG. Given that both TrkC+ proprioceptors and TrkA+ nociceptors are being born at this time point, we sought to determine whether geographically distinct regions within the perimeter might preferentially give rise to different neuronal subtypes and/or glial cells. To map potential progenitor zones within the developing DRG we assayed for mitotic activity via a pulse of bromodeoxyuridine (BrdU) at four developmental time points: E4/St.23, during the first wave of neurogenesis and prior to the second wave; E4.5/St.25, corresponding to the continued birth of TrkC+ and TrkB+ neurons and to the first appearance of TrkA+ neurons; E5/St.27, approaching the end of the first wave and coinciding with a sharp increase in the number of TrkA+ neurons; and E6.5/St.30, after the first wave and approaching the end of the second wave. At these same time points we also analyzed expression of Sox10 and Pax3, two genes involved in the maintenance of NCC pluripotency (Koblar et al., 1999; Kuhlbrodt et al., 1998; Maka et al., 2005). At St.23, mitotically active cells were found along the entire DRG perimeter as well as dispersed throughout the core (Fig. 2A). All Sox10+ cells were Pax3+ at this time point with more double positive cells along the lateral vs. the medial perimeter (Fig. 2B-D). While Sox 10 immunolabeling intensity was consistent throughout the perimeter, Pax 3 expression was more robust in the lateral perimeter and ventral pole as compared to the medial perimeter and dorsal pole (Fig. 2C). Sox10+/Pax3+ cells were frequently mitotically active (Fig. 2E). At E4.5/St.25, while both the BrdU and Sox 10 patterns were unchanged (Fig. 2F,G), the bias in Pax3 intensity shifted from the lateral perimeter and ventral pole to the medial perimeter and dorsal pole (Fig. 2H,I) with numerous Sox 10+ cells in the VL perimeter now being Pax3- (Fig. 2I,J, arrowheads). At E5/ St.27, the pattern of mitotic activity now diverged from previous time points with BrdU+ cells only rarely present along the VL perimeter of the DRG and abundant along the medial perimeter (Fig. 2K). At this time point, Sox 10 and Pax3 expression patterns were strikingly divergent. Although Sox10+ cells were still present along the entire DRG perimeter, they were clearly more abundant and immunoreactive in the VL perimeter and ventral pole (Fig. $2 \mathrm{~L}, \mathrm{~N}$ ). In addition, a wave of Sox $10+$ cells extended medially into the DRG interior, likely corresponding to the proliferation/migration of glial progenitors (Carr and Simpson, 1978; Kuhlbrodt et al., 1998). In contrast, Pax3 expression was clearly restricted to the medial perimeter, dorsal pole, and a short segment of the DL perimeter (Fig. 2M,N), with numerous mitotically active Pax3+ cells (Supplemental Fig. 1). Along the medial DRG, Pax3 expression was more robust than at any previous time point and included numerous Pax3+l Sox10- cells (Fig. 2N, inset), a molecular profile not present previously. Given the coincident colonization of this same region by contralaterally migrating NCCs (Fig. 1J), we tested whether these contralateral cells express Pax 3 and found that in fact, most EGFP+ cells within the medial perimeter and dorsal pole of the contralateral DRG were Pax3+ (Fig. $2 \mathrm{O}$, arrowheads). At E6.5/St.30, mitotic cells and Pax3 expression were both restricted to the DRG dorsal root/pole and DM perimeter (Fig. 2P,Q). Expression of NeuroM, a transcription factor specific to post-mitotic neuronal precursor cells (Roztocil et al., 1997), 
was also restricted to this region (Fig. 2R), indicating that progenitors within the dorsal pole and DM perimeter likely give rise to the last neurons born in the DRG. Sox10 expression remained robust within the VL perimeter, spreading even farther medially than the previous stage (Fig. 2S). Based on the close juxtaposition of these Sox10+/Pax3- cells with neurons (Fig. 2T), they are most likely glia or glial precursors.

These data demonstrate the temporal development of three geographically and molecularly distinct progenitor/precursor zones within the DRG perimeter (Fig. 2): 1) Sox10+/Pax3+ cells along the entire DRG perimeter prior to St.25 and restricted to the dorsal pole and DM perimeter after St.25; 2) Sox10+/Pax3- cells appearing at approximately St.25 in the VL perimeter and spreading throughout the DRG in a DM wave; and 3) robustly Pax3+ progenitors (including Pax3+/Sox 10- cells) derived from contralaterally migrating NCCs that colonize the DRG dorsal pole and medial perimeter during St.25-27.

\section{Perimeter-localized progenitor cells give rise to daughters that migrate inward toward a concentric zone of neuronal differentiation}

To assess the migratory behavior and colonization pattern of perimeter-localized progenitors and their daughter cells, we injected DiI into discrete regions of the DRG perimeter in transverse slices prepared from St.25 embryos (Fig. 3A). These slices have been used successfully to study many events in neural differentiation since they retain normal tissue morphology and support normal neuronal development (Krull and Kulesa, 1998;Landmesser et al., 1988). After injection, the initial diameter of the labeled cell mass was measured, followed by a 24-hour culture and final measurement of the labeled daughter cell spread. Inward migration occurred with injection into each of the selected regions (Fig. 3B-D).

To visualize the cellular dynamics, including filopodial interactions, cell division, and migration that perimeter-localized progenitor cells undergo as they give rise to neurons, we utilized a Hes 1 EGFP reporter construct (Ohtsuka et al., 2006). It is well established that Hes1, a basic Helix-Loop-Helix (bHLH) transcription factor and downstream target of Notch, is required for both the maintenance of a neural progenitor state as well as progression through neurogenesis (Guillemot et al., 2006; Jan and Jan, 1994; Kinameri et al., 2008; Ohtsuka et al., 1999; Shirasaki and Pfaff, 2002). Both in situ hybridization (not shown) and the Hesl reporter (Fig. 3E) indicated that Hesl expression is limited to the DRG perimeter. Using time-lapse confocal microscopy we imaged the behavior and proliferation of cells expressing the Hes 1 reporter in live tissue explants (Fig. 3E-Q). As shown, two EGFP+ progenitors within the VL perimeter of the DRG extend filopodia in a DM direction into the ganglion interior (cell $1=$ blue arrowhead in Fig. 3F-N; cell $2=$ red arrowhead in Fig. 3M-Q), where they contact a faint, more interior EGFP+ cell (Fig. 3H,M arrows). After making this contact, both perimeter cells divide on a cleavage plane that produces one medial and one lateral daughter (Fig. 3K,O). Following division, both medial daughters migrate along the same route previously explored by their mother cell's filopodium to the interior of the DRG (cell 1, Fig. 3K-N; cell 2, Fig. 3O-Q), while the lateral daughters remain in the perimeter (cell 1, Fig. 3N arrow; cell 2, Fig. 3Q arrow). Multiple progenitor cells in other regions of the perimeter, including the medial region, undergo similar divisions (not shown). To trace the emergence of nascent neurons from perimeter-localized progenitors, we analyzed the expression of the NeuroM reporter in combination with immunolabeling for Sox 10 and Tuj-1. The combined imaging of these markers shows that the NeuroM reporter is expressed by a cell layer immediately interior to the Sox 10+ DRG perimeter, and exterior to the Tuj-1+ neuronal core, identifying a novel intermediate concentric zone of neural differentiation (Fig. 3R). In combination, these data indicate that the mitotic activity of perimeter-localized progenitors contributes to both the expansion of the neuronal core by generating daughter cells that migrate inward to a zone of neural differentiation, and to the 
maintenance of the outer proliferative zone by producing daughter cells that remain in the DRG perimeter.

\section{Pax3+ progenitors in the IOMZ generate TrkA+ neurons that are born late and exclusively within the dorsal-medial DRG}

A dramatic increase in the number of TrkA+ DRG neurons initiates at E5/St.27 (Rifkin et al., 2000). Since this increase coincides with the emergence of distinct Pax3+ vs. Pax3zones within the perimeter, we sought to determine from which regions TrkA+ neurons derive. The Pax3+ zone appears during St.25-27 and its location is the same as the IOMZ (Hamburger et al., 1981)(Fig. 2M). Based on its DM position, the authors posited that this zone gives rise to second wave neurons. In agreement with this, we show that mitotic activity is limited to this very region at St.27 (Fig. 2K). Furthermore, some newly differentiating neurons at least transiently express the Pax3 antigen (Fig. 4A), further indicating that Pax3 marks neuronal progenitor cells.

To directly trace the lineage of mitotic progenitors within the IOMZ, embryos were injected with BrdU at St.26/27, fixed at stages 28 and 32/33, and immunolabeled with neuronal markers including Tuj-1 and TrkA. In most sections from embryos fixed at St.28, BrdU+ cells were limited in number and were clearly confined to the medial or DM $1 / 3$ of the ganglion (Fig. 4B). In contrast, TrkA+ cells were numerous and spread throughout the DRG including the entire VL region. Some sections showed minimal DM localization with the most VL margin being devoid of TrkA+ cells (Fig. 4C, arrow). Surprisingly, very few of the BrdU+ cells present in these sections expressed neuronal markers including TrkA (Fig. 4C,D) and Tuj-1 (not shown). In embryos fixed at St.32/33 BrdU+ cells were now abundant and distinctly localized to the DM $2 / 3$ of the DRG (Fig. 4E). TrkA expression was also clearly confined to this same region and overlays showed that most BrdU+ cells were now also TrkA+ (Fig. 4G,H). These data show that mitotically active, Pax3+ progenitors in the IOMZ, that derived from contralaterally migrating NCCs, specifically give rise to TrkA+ neurons that are born in the DM DRG and initiate TrkA expression after St.28.

\section{Early TrkA+ neurons derive from Sox10+/Pax3+ progenitors that are dispersed throughout the DRG perimeter}

Prior to this relatively late genesis of TrkA+ neurons within the DM $2 / 3$ of the DRG, there is a large population of TrkA+ afferents distributed throughout the ganglion (Fig. 4C). Since these early TrkA+ neurons are not labeled by BrdU injections at St.26/27, they likely derive from a progenitor pool distinct from the IOMZ. To identify the progenitor cells that give rise to these early TrkA+ neurons, embryos were injected with BrdU at St.23, when mitotically active cells circumscribe the entire ganglion, and fixed at St.25, when TrkA+ neurons first appear, but prior to significant development of the IOMZ (Fig. 2H). In these embryos, most TrkA+ cells, including both DM and VL, were BrdU+ (Supplemental Fig. 2A).

To determine if specific regions within the DRG perimeter preferentially give rise to the early subset of TrkA neurons, we ablated three regions of the ganglion: the medial perimeter, the dorsal root/pole, and the lateral perimeter in E4-4.5/St.23-25 trunk slices (Fig. $5 \mathrm{~A}-\mathrm{C})$. Ablation of a single ganglionic region per slice was followed by a 24-hour culture period, a time frame corresponding to the birth of the first TrkA neurons in vivo, and the number of TrkA+ neurons quantified in both the operated and non-operated DRG. As expected based on the distribution of progenitors throughout the perimeter at St.25, ablation of each zone resulted in decreased TrkA+ numbers, however lateral perimeter ablations resulted in the most significant loss (65\%) (Fig. 5D-F). Neuronal morphology in ablated ganglia was similar to that in intact ganglia (Supplemental Fig. 2B-I) indicating that the observed reduction in TrkA number was due to the elimination of TrkA progenitor cells, 
rather than to a generalized loss of tissue integrity or the destruction of support cells. To further assess the impact of lateral perimeter ablations on the neuronal population as a whole, ablated ganglia were also immunolabeled with Trks B and C. Although the TrkB+ population appeared less affected by these ablations as compared to TrkA+ neurons (Supplemental Fig. 2D-F), TrkB numbers were still reduced by 38\% $( \pm 8.6 \%)(\mathrm{n}=4$ slices). The number of TrkC+ neurons was not quantified, however this population appeared to be impacted the least (Supplemental Fig. 2G-I), an anticipated result given the relatively large number of TrkC+ neurons already present in the DRG at St.23-25. As a final control, mesoderm tissue lateral to a single ganglion was also ablated, resulting in a minor decrease in TrkA+ numbers (Fig. 5D).

As an additional means for testing whether the lateral DRG perimeter contributes to the subset of TrkA+ neurons that are born early in development, fluorescent micro-beads were injected into the lateral perimeter of the DRG in St.25 embryonic slice preparations. These beads label cells via phagocytosis (Steinkamp et al., 1982), as well as by sticking to cell membranes (Katz et al., 1984). Slices were photographed immediately after injection, as well as after 27 hours of culture, to map the initial and final distribution (Fig. 5G,H), followed by immunolabeling with anti TrkA antibody. Bead-labeled, TrkA+ neurons were consistently found in the interior of the DRG in both VL and DM positions (Fig. 5I,J); Supplemental Fig. 2J). These experiments demonstrate that the early subset of TrkA+ neurons, those that express TrkA prior to St.28 and that appear in a uniform distribution throughout the DRG, derive from Sox 10+/Pax3+ progenitors located throughout the ganglion perimeter, with those in the VL perimeter making the greatest contribution.

\section{Discussion}

In this report we identify the spatial and temporal patterns in neural crest migration and neurogenesis that mediate the emergence of the DRG. Our data provide a mechanistic explanation for the patterned migration of ipsilateral versus contralateral NCCs, and the segregation of early post mitotic neurons to the DRG core versus proliferative progenitors to the DRG perimeter. We demonstrate how progenitor cells residing in the dynamic proliferative layer that surrounds the DRG mediate the second wave of neurogenesis, and that TrkA+ neurons derive from two distinct pools of progenitor cells based on timing, their geographic location within the DRG perimeter, and their differential expression of key genes regulating terminal differentiation.

The findings presented here, in combination with previously published data (George et al., 2007; Marmigere and Ernfors, 2007; Montelius et al., 2007; Rifkin et al., 2000) are summarized in the schematic shown in Fig. 6. According to this model, the first DRG neurons are born at St.15/16 from Ngn2+ NCCs that delaminate from lateral positions along the dorsal neural tube. These first sensory afferents form a nucleus around which additional NCCs and differentiating neurons coalesce, generating numerous TrkB+/TrkC+ neurons within the DRG core. (Ma et al., 1999; Montelius et al., 2007). Ngn2- NCCs delaminate from positions closer to the dorsal midline and primarily colonize the lateral perimeter and dorsal pole of the DRG. This initial patterning of Ngn2+ versus Ngn2- NCCs contributes to the segregation of differentiated neurons to the DRG core and undifferentiated progenitors to the perimeter. In essence, this nascent cytoarchitecture functions as an inside-out version of the CNS ventricular zone and mantle. In addition to the patterning mechanisms just described, differential expression of cell adhesion molecules may also play a role in the segregation of neurons from perimeter cells (Bononi et al., 2008). Finally, time-lapse images suggest that an active recognition via filopodial contact directs the behavior of differentiating neurons and progenitors (Fig. 3F-Q). 
Within the developing DRG perimeter, progenitor cells proliferate and over time give rise to three geographically and molecularly distinct progenitor zones. Sox $10+/ \mathrm{Pax} 3+$ progenitors appear first, circumscribing the entire ganglion, and at St.23-25 begin medial/lateral divisions. Lateral daughters cease Pax3 expression and maintain Sox10, while medial daughters cease Sox 10 and transiently express both Pax 3 and NeuroM as they migrate inward through a zone of neuronal differentiation, behaviors consistent with previous work demonstrating that Sox 10 expression is extinguished as progenitor cells differentiate toward the neuronal lineage (Sonnenberg-Riethmacher et al., 2001). This inward migration and differentiation of daughter cells derived from Sox 10+/Pax3+ progenitors in the DRG perimeter generates the majority of $\mathrm{TrkB}+/ \mathrm{TrkC}+/ \mathrm{TrkA}$ - neurons, and the early subset of TrkA+ neurons. These early nociceptive afferents, as well as many of the TrkA+ neurons born after St. 28 (see below), likely coexpress at least one of the other Trk receptors until their down-regulation later in development (Rifkin et al., 2000). Lateral Pax3- daughters that maintain Sox 10 expression comprise the second class of progenitors within the DRG perimeter and presumably give rise to glia since Sox 10 is required for glial fate acquisition (Paratore et al., 2001). During this same time frame, the progeny of contralaterally-derived NCCs within the dorsal root and pole proliferate, giving rise to a population of robustly Pax $3+$ cells that comprise the third class of perimeter-localized progenitor cells. These progenitors colonize the entire medial perimeter as well as a short segment of the DL perimeter, as first described by Hamburger et al. (1981), and specifically give rise to DM TrkA+ afferents that initiate TrkA expression after St.28. These progenitors also include boundary cap cells (George et al., 2007) that generate a small percentage of TrkA+ neurons (Maro et al., 2004). The fate of early TrkA+ neurons born in the VL lobe of the DRG remains unresolved. Since in the mature ganglion TrkA+ neurons are rare in VL locations, these afferents either die during the subsequent period of programmed cell death (Carr and Simpson, 1978; Hamburger and Levi-Montalcini, 1949), migrate into more dorsal positions, or remain in the VL DRG but down regulate TrkA (Rifkin et al., 2000).

In a retroviral lineage analysis two types of neuronal clones were identified: large clones containing both neuronal and non-neuronal cells, and small clones composed only of neurons (Frank and Sanes, 1991). Mixed clones contained not only a larger total number of cells, but also contained approximately four times more neurons as compared to the neurononly clones. Contralaterally migrating NCCs that colonize the DRG perimeter likely give rise to mixed clones since they are prolific (George et al., 2007), and appear to generate both neurons and glia. Mouse knockout experiments indicate that $\mathrm{Ngn} 2$ drives the genesis of VL TrkC+ and TrkB+ neurons during the first wave of neurogenesis, while $\mathrm{Ngnl}$ is required for the generation of DM TrkA+ and a subset of TrkC+/TrkB+ neurons during the second wave (Ma et al., 1999). Although Ngn2 is strongly expressed at St.15, when Ngnl expression is negligible (Perez et al., 1999), both genes are co-expressed slightly later, with the onset of Ngn1 expression likely being Ngn2 dependent (Ma et al., 1999). In the retroviral lineage analysis, the small VL neuronal clones were found only when viral infection was performed early, at St.13-16, suggesting the existence of a distinct, early precursor population with limited proliferative capacity that is Ngn2 dependent (Ma et al., 1999). Since the robustly immunoreactive $\mathrm{Ngn} 2+\mathrm{NCCs}$ identified here that migrate almost exclusively ipsilaterally and give rise to the first neurons born in the DRG are present at St.15, they likely constitute this early neuron-specific precursor population previously described (Frank and Sanes, 1991; Ma et al., 1999). The association of Ngn2 with exclusively VL neuronal clones conflicts with reporter based lineage tracing experiments showing that $\mathrm{Ngn} 2$ progenitors give rise to TrkA+ DM afferents and glia, as well as TrkC+ and TrkB+ VL neurons (Zirlinger et al., 2002). However, these reporter experiments by design included both the early NCCs that exclusively express Ngn2, as well as NCCs that migrate slightly later and coexpress both $\mathrm{Ngn2}$ and $\mathrm{Ngnl}$. Thus the increased multipotency and proliferative capacity observed in this Ngn2 study may reflect the combined actions of both the Ngn genes, with 
$N g n 1$ expression likely induced by transient expression of $N g n 2$. In this study we report a very small percentage of contralaterally migrating NCCs (3.5\%) that were $\mathrm{Ngn} 2+$. Since lineage-tracing studies show that contralaterally migrating NCCs give rise to the second, Ngnl-dependent wave of neurogenesis (George et al., 2007), these contralateral Ngn2+ cells may represent those NCCs that will later co-express Ngnl.

Both Sox 10+ and Pax3+ cells have been previously identified in the avian DRG, however these data are the first to document dynamic temporal and spatial changes in the expression of these proteins, and thereby identify distinct subpopulations of progenitors. The robust expression of Pax3 during DRG development supports previous studies indicating that Pax3 plays a key role in sensory neuron differentiation (Koblar et al., 1999; Nakazaki et al., 2008). Interestingly, TrkA+ afferents first appear in the DRG as Pax3 expression recedes. Similarly, the birth of late, TrkA+ neurons in the DM DRG progresses as Pax3 decreases within the IOMZ. In the absence of functional Pax3, mouse neural crest cells undergo premature neurogenesis, indicating a role in the maintenance of an undifferentiated state (Nakazaki et al., 2008). Pax3 plays a dual role in the differentiation of pigment cells by both directing melanocyte fate and simultaneously preventing terminal differentiation (Lang et al., 2005). In a similar fashion, our data indicate that neural crest stem cells may be specified toward a neuronal fate by Pax3, but do not terminally differentiate until after Pax3 expression ceases. Pax3 was recently shown to regulate the activities of Hesl and Ngn2 (Nakazaki et al., 2008). Although a binding affinity for Ngnl was not tested, both Pax3 and Ngn1 are strongly expressed in the IOMZ at St.27 (Fig. 2M; Perez et al., 1999). Thus, Pax3 may also regulate the expression of $\mathrm{Ngnl}$, a key player in the second wave of neurogenesis (Ma et al., 1999).

An ongoing discussion is to what extent neural crest cells are specified prior to their migration. Many published studies show that timing affects NCC fate (Ma et al., 1999; Reedy et al., 1998; Serbedzija et al., 1989), while other studies indicate that identity is directly related to premigratory position within the neural tube (Dorsky et al., 1998; 2000; Lo et al., 2005). The data presented here indicate that both of these factors are involved in cell type specification, and that further exploration of spatial positioning within the neural tube is warranted. Following the completion of neurogenesis, an outstanding question has been how subtypes of sensory neurons establish their unique identities. Several transcription factors are known to drive the differentiation of TrkA+ (nociceptors and thermoreceptors) vs. TrkB+ (mechanoreceptors) vs. TrkC+ (proprioceptors) cell populations (Chen et al., 2006; Kramer et al., 2006; Levanon et al., 2002; Marmigere et al., 2006). However, the TrkA+ subset of DRG neurons is itself an extremely heterogeneous population including multiple types of thermoreceptors and nociceptors. With the identification in this study of two temporally and spatially distinct neurogenic waves that both give rise to TrkA+ neurons, but are generated by molecularly distinct populations of progenitor cells, we are now positioned to ask whether these distinct lineages give rise to different subpopulations of small diameter sensory neurons.

\section{Supplementary Material}

Refer to Web version on PubMed Central for supplementary material.

\section{Acknowledgments}

We are grateful to Dr. Michael Wegner (Universität Erlangen-Nürnberg), Dr. Ben Novitch (University of California, Los Angeles), and to Dr. Rusty Lansford (Caltech) for their generous gifts of the Sox 10 antibody, the Ngn2 antibody, and the EGFP virus, respectively. 
This work was supported by the National Institutes of Health, National Institute of Neurological Disorders and Stroke R01 35714 (F.L.), NIH NRSA 7055571 (L.G.), NIH grant P20RR015583 from the COBRE program of NCRR (L.G.), and NIH National Institute of Mental Health, MH078998 (N.K.)

\section{References}

Abercrombie M. Estimation of nuclear population from microtome sections. The Anatomical Record. 1946; 94:239-247. [PubMed: 21015608]

Arber S, Ladle DR, Lin JH, Frank E, Jessell TM. ETS gene Er81 controls the formation of functional connections between group Ia sensory afferents and motor neurons. Cell. 2000; 101(5):485-498. [PubMed: 10850491]

Baker CV, Stark MR, Marcelle C, Bronner-Fraser M. Competence, specification and induction of Pax-3 in the trigeminal placode. Development. 1999; 126(1):147-156. [PubMed: 9834194]

Bononi J, Cole A, Tewson P, Schumacher A, Bradley R. Chicken protocadherin-1 functions to localize neural crest cells to the dorsal root ganglia during PNS formation. Mech Dev. 2008; 125(11-12): 1033-1047. [PubMed: 18718533]

Carr VM, Simpson SB Jr. Proliferative and degenerative events in the early development of chick dorsal root ganglia. II. Responses to altered peripheral fields. J Comp Neurol. 1978; 182(4):741755. [PubMed: 721976]

Chen CL, Broom DC, Liu Y, de Nooij JC, Li Z, Cen C, Samad OA, Jessell TM, Woolf CJ, Ma Q. Runx 1 determines nociceptive sensory neuron phenotype and is required for thermal and neuropathic pain. Neuron. 2006; 49(3):365-377. [PubMed: 16446141]

Dorsky RI, Moon RT, Raible DW. Control of neural crest cell fate by the Wnt signalling pathway. Nature. 1998; 396(6709):370-373. [PubMed: 9845073]

Dorsky RI, Moon RT, Raible DW. Environmental signals and cell fate specification in premigratory neural crest. Bioessays. 2000; 22(8):708-716. [PubMed: 10918301]

Frank E, Sanes JR. Lineage of neurons and glia in chick dorsal root ganglia: analysis in vivo with a recombinant retrovirus. Development. 1991; 111(4):895-908. [PubMed: 1908772]

Gallo G, Lefcort FB, Letourneau PC. The trkA receptor mediates growth cone turning toward a localized source of nerve growth factor. J Neurosci. 1997; 17(14):5445-5454. [PubMed: 9204927]

George L, Chaverra M, Todd V, Lansford R, Lefcort F. Nociceptive sensory neurons derive from contralaterally migrating, fate-restricted neural crest cells. Nat Neurosci. 2007; 10(10):1287-1293. [PubMed: 17828258]

Granger BL, Lazarides E. Expression of the major neurofilament subunit in chicken erythrocytes. Science. 1983; 221(4610):553-556. [PubMed: 6346488]

Gratzner HG. Monoclonal antibody to 5-bromo- and 5-iododeoxyuridine: A new reagent for detection of DNA replication. Science. 1982; 218(4571):474-475. [PubMed: 7123245]

Guillemot F, Molnar Z, Tarabykin V, Stoykova A. Molecular mechanisms of cortical differentiation. Eur J Neurosci. 2006; 23(4):857-868. [PubMed: 16519651]

Guillery RW. On counting and counting errors. J Comp Neurol. 2002; 447(1):1-7. [PubMed: 11967890]

Hamburger V, Brunso-Bechtold JK, Yip JW. Neuronal death in the spinal ganglia of the chick embryo and its reduction by nerve growth factor. J Neurosci. 1981; 1(1):60-71. [PubMed: 7346558]

Hamburger V, Hamilton HL. A series of normal stages in the development of the chick embryo. 1951. Dev Dyn. 1992; 195(4):231-272. [PubMed: 1304821]

Hamburger V, Levi-Montalcini R. Proliferation, differentiation and degeneration in the spinal ganglia of the chick embryo under normal and experimental conditions. J Exp Zool. 1949; 111(3):457501. [PubMed: 18142378]

Hippenmeyer S, Vrieseling E, Sigrist M, Portmann T, Laengle C, Ladle DR, Arber S. A developmental switch in the response of DRG neurons to ETS transcription factor signaling. PLoS Biol. 2005; 3(5):e159. [PubMed: 15836427]

Jan YN, Jan LY. Genetic control of cell fate specification in Drosophila peripheral nervous system. Annu Rev Genet. 1994; 28:373-393. [PubMed: 7893132] 
Karlsson M, Clary DO, Lefcort FB, Reichardt LF, Karten HJ, Hallbook F. Nerve growth factor receptor TrkA is expressed by horizontal and amacrine cells during chicken retinal development. J Comp Neurol. 1998; 400(3):408-416. [PubMed: 9779944]

Katz LC, Burkhalter A, Dreyer WJ. Fluorescent latex microspheres as a retrograde neuronal marker for in vivo and in vitro studies of visual cortex. Nature. 1984; 310(5977):498-500. [PubMed: 6205278]

Kinameri E, Inoue T, Aruga J, Imayoshi I, Kageyama R, Shimogori T, Moore AW. Prdm protooncogene transcription factor family expression and interaction with the Notch-Hes pathway in mouse neurogenesis. PLoS ONE. 2008; 3(12):e3859. [PubMed: 19050759]

Koblar SA, Murphy M, Barrett GL, Underhill A, Gros P, Bartlett PF. Pax-3 regulates neurogenesis in neural crest-derived precursor cells. J Neurosci Res. 1999; 56(5):518-530. [PubMed: 10369218]

Kramer I, Sigrist M, de Nooij JC, Taniuchi I, Jessell TM, Arber S. A role for Runx transcription factor signaling in dorsal root ganglion sensory neuron diversification. Neuron. 2006; 49(3):379-393. [PubMed: 16446142]

Krull CE. A primer on using in ovo electroporation to analyze gene function. Dev Dyn. 2004; 229(3): 433-439. [PubMed: 14991698]

Krull CE, Kulesa PM. Embryonic explant and slice preparations for studies of cell migration and axon guidance. Curr Top Dev Biol. 1998; 36:145-159. [PubMed: 9342526]

Kuhlbrodt K, Herbarth B, Sock E, Hermans-Borgmeyer I, Wegner M. Sox10, a novel transcriptional modulator in glial cells. J Neurosci. 1998; 18(1):237-250. [PubMed: 9412504]

Landmesser L, Dahm L, Schultz K, Rutishauser U. Distinct roles for adhesion molecules during innervation of embryonic chick muscle. Dev Biol. 1988; 130(2):645-670. [PubMed: 3058545]

Lang D, Lu MM, Huang L, Engleka KA, Zhang M, Chu EY, Lipner S, Skoultchi A, Millar SE, Epstein JA. Pax3 functions at a nodal point in melanocyte stem cell differentiation. Nature. 2005; 433(7028):884-887. [PubMed: 15729346]

Lee MK, Tuttle JB, Rebhun LI, Cleveland DW, Frankfurter A. The expression and posttranslational modification of a neuron-specific beta-tubulin isotype during chick embryogenesis. Cell Motil Cytoskeleton. 1990; 17(2):118-132. [PubMed: 2257630]

Levanon D, Bettoun D, Harris-Cerruti C, Woolf E, Negreanu V, Eilam R, Bernstein Y, Goldenberg D, Xiao C, Fliegauf M, Kremer E, Otto F, Brenner O, Lev-Tov A, Groner Y. The Runx3 transcription factor regulates development and survival of TrkC dorsal root ganglia neurons. EMBO J. 2002; 21(13):3454-3463. [PubMed: 12093746]

Lin JH, Saito T, Anderson DJ, Lance-Jones C, Jessell TM, Arber S. Functionally related motor neuron pool and muscle sensory afferent subtypes defined by coordinate ETS gene expression. Cell. 1998; 95(3):393-407. [PubMed: 9814709]

Liu JP, Jessell TM. A role for rhoB in the delamination of neural crest cells from the dorsal neural tube. Development. 1998; 125(24):5055-5067. [PubMed: 9811589]

Lo L, Dormand EL, Anderson DJ. Late-emigrating neural crest cells in the roof plate are restricted to a sensory fate by GDF7. Proc Natl Acad Sci U S A. 2005; 102(20):7192-7197. [PubMed: 15883363]

Ma Q, Fode C, Guillemot F, Anderson DJ. Neurogenin1 and neurogenin2 control two distinct waves of neurogenesis in developing dorsal root ganglia. Genes Dev. 1999; 13(13):1717-1728. [PubMed: 10398684]

Maka M, Stolt CC, Wegner M. Identification of Sox8 as a modifier gene in a mouse model of Hirschsprung disease reveals underlying molecular defect. Dev Biol. 2005; 277(1):155-169. [PubMed: 15572147]

Marmigere F, Ernfors P. Specification and connectivity of neuronal subtypes in the sensory lineage. Nat Rev Neurosci. 2007; 8(2):114-127. [PubMed: 17237804]

Marmigere F, Montelius A, Wegner M, Groner Y, Reichardt LF, Ernfors P. The Runx1/AML1 transcription factor selectively regulates development and survival of TrkA nociceptive sensory neurons. Nat Neurosci. 2006; 9(2):180-187. [PubMed: 16429136]

Maro GS, Vermeren M, Voiculescu O, Melton L, Cohen J, Charnay P, Topilko P. Neural crest boundary cap cells constitute a source of neuronal and glial cells of the PNS. Nat Neurosci. 2004; 7(9):930-938. [PubMed: 15322547] 
Meyer JS, Nauert J, Koehm S, Hughes J. Cell kinetics of human tumors by in vitro bromodeoxyuridine labeling. J Histochem Cytochem. 1989; 37(9):1449-1454. [PubMed: 2768814]

Montelius A, Marmigere F, Baudet C, Aquino JB, Enerback S, Ernfors P. Emergence of the sensory nervous system as defined by Foxs1 expression. Differentiation. 2007; 75(5):404-417. [PubMed: 17309606]

Muramatsu T, Mizutani Y, Ohmori Y, Okumura J. Comparison of three nonviral transfection methods for foreign gene expression in early chicken embryos in ovo. Biochem Biophys Res Commun. 1997; 230(2):376-380. [PubMed: 9016787]

Nakamura S, Senzaki K, Yoshikawa M, Nishimura M, Inoue K, Ito Y, Ozaki S, Shiga T. Dynamic regulation of the expression of neurotrophin receptors by Runx3. Development. 2008; 135(9): 1703-1711. [PubMed: 18385258]

Nakazaki H, Reddy AC, Mania-Farnell BL, Shen YW, Ichi S, McCabe C, George D, McLone DG, Tomita T, Mayanil CS. Key basic helix-loop-helix transcription factor genes Hes1 and Ngn2 are regulated by Pax3 during mouse embryonic development. Dev Biol. 2008; 316(2):510-523. [PubMed: 18308300]

Nelson BR, Matsuhashi S, Lefcort F. Restricted neural epidermal growth factor-like like 2 (NELL2) expression during muscle and neuronal differentiation. Mech Dev. 2002; 119(Suppl 1):S11-19. [PubMed: 14516654]

Nelson BR, Reh TA. Relationship between Delta-like and proneural bHLH genes during chick retinal development. Dev Dyn. 2008; 237(6):1565-1580. [PubMed: 18435466]

Novitch BG, Chen AI, Jessell TM. Coordinate regulation of motor neuron subtype identity and panneuronal properties by the bHLH repressor Olig2. Neuron. 2001; 31(5):773-789. [PubMed: 11567616]

Oakley RA, Lefcort FB, Clary DO, Reichardt LF, Prevette D, Oppenheim RW, Frank E. Neurotrophin-3 promotes the differentiation of muscle spindle afferents in the absence of peripheral targets. J Neurosci. 1997; 17(11):4262-4274. [PubMed: 9151743]

Ohtsuka T, Imayoshi I, Shimojo H, Nishi E, Kageyama R, McConnell SK. Visualization of embryonic neural stem cells using Hes promoters in transgenic mice. Mol Cell Neurosci. 2006; 31(1):109122. [PubMed: 16214363]

Ohtsuka T, Ishibashi M, Gradwohl G, Nakanishi S, Guillemot F, Kageyama R. Hes1 and Hes5 as notch effectors in mammalian neuronal differentiation. EMBO J. 1999; 18(8):2196-2207. [PubMed: 10205173]

Okada A, Lansford R, Weimann JM, Fraser SE, McConnell SK. Imaging cells in the developing nervous system with retrovirus expressing modified green fluorescent protein. Exp Neurol. 1999; 156(2):394-406. [PubMed: 10328944]

Osumi N, Inoue T. Gene transfer into cultured mammalian embryos by electroporation. Methods. 2001; 24(1):35-42. [PubMed: 11327800]

Paratore C, Goerich DE, Suter U, Wegner M, Sommer L. Survival and glial fate acquisition of neural crest cells are regulated by an interplay between the transcription factor Sox 10 and extrinsic combinatorial signaling. Development. 2001; 128(20):3949-3961. [PubMed: 11641219]

Patapoutian A. Making the pain connection. Neuron. 2001; 31(1):4-6. [PubMed: 11498043]

Patapoutian A, Peier AM, Story GM, Viswanath V. ThermoTRP channels and beyond: mechanisms of temperature sensation. Nat Rev Neurosci. 2003; 4(7):529-539. [PubMed: 12838328]

Perez SE, Rebelo S, Anderson DJ. Early specification of sensory neuron fate revealed by expression and function of neurogenins in the chick embryo. Development. 1999; 126(8):1715-1728. [PubMed: 10079233]

Pourquie O, Coltey M, Thomas JL, Le Douarin NM. A widely distributed antigen developmentally regulated in the nervous system. Development. 1990; 109(4):743-752. [PubMed: 2226198]

Reedy MV, Faraco CD, Erickson CA. The delayed entry of thoracic neural crest cells into the dorsolateral path is a consequence of the late emigration of melanogenic neural crest cells from the neural tube. Dev Biol. 1998; 200(2):234-246. [PubMed: 9705230]

Rifkin JT, Todd VJ, Anderson LW, Lefcort F. Dynamic expression of neurotrophin receptors during sensory neuron genesis and differentiation. Dev Biol. 2000; 227(2):465-480. [PubMed: 11071767] 
Roztocil T, Matter-Sadzinski L, Alliod C, Ballivet M, Matter JM. NeuroM, a neural helix-loop-helix transcription factor, defines a new transition stage in neurogenesis. Development. 1997; 124(17): 3263-3272. [PubMed: 9310321]

Schropel A, von Schack D, Dechant G, Barde YA. Early expression of the nerve growth factor receptor ctrkA in chick sympathetic and sensory ganglia. Mol Cell Neurosci. 1995; 6(6):544-566. [PubMed: 8742271]

Scott, SA. Sensory neurons: diversity development and plasticity. Oxford University Press; New York: 1992.

Serbedzija GN, Bronner-Fraser M, Fraser SE. A vital dye analysis of the timing and pathways of avian trunk neural crest cell migration. Development. 1989; 106(4):809-816. [PubMed: 2562671]

Sharma K, Korade Z, Frank E. Late-migrating neuroepithelial cells from the spinal cord differentiate into sensory ganglion cells and melanocytes. Neuron. 1995; 14(1):143-152. [PubMed: 7826632]

Shirasaki R, Pfaff SL. Transcriptional codes and the control of neuronal identity. Annu Rev Neurosci. 2002; 25:251-281. [PubMed: 12052910]

Sonnenberg-Riethmacher E, Miehe M, Stolt CC, Goerich DE, Wegner M, Riethmacher D. Development and degeneration of dorsal root ganglia in the absence of the HMG-domain transcription factor Sox 10. Mech Dev. 2001; 109(2):253-265. [PubMed: 11731238]

Stark MR, Sechrist J, Bronner-Fraser M, Marcelle C. Neural tube-ectoderm interactions are required for trigeminal placode formation. Development. 1997; 124(21):4287-4295. [PubMed: 9334277]

Steinkamp JA, Wilson JS, Saunders GC, Stewart CC. Phagocytosis: flow cytometric quantitation with fluorescent microspheres. Science. 1982; 215(4528):64-66. [PubMed: 7053559]

Stolt CC, Lommes P, Sock E, Chaboissier MC, Schedl A, Wegner M. The Sox 9 transcription factor determines glial fate choice in the developing spinal cord. Genes Dev. 2003; 17(13):1677-1689. [PubMed: 12842915]

Teddy JM, Lansford R, Kulesa PM. Four-color, 4-D time-lapse confocal imaging of chick embryos. Biotechniques. 2005; 39(5):703-710. [PubMed: 16312219]

v Holst A, Lefcort F, Rohrer H. TrkA expression levels of sympathetic neurons correlate with NGFdependent survival during development and after treatment with retinoic acid. Eur J Neurosci. 1997; 9(10):2169-2177. [PubMed: 9421176]

Venters SJ, Argent RE, Deegan FM, Perez-Baron G, Wong TS, Tidyman WE, Denetclaw WF Jr. Marcelle C, Bronner-Fraser M, Ordahl CP. Precocious terminal differentiation of premigratory limb muscle precursor cells requires positive signalling. Dev Dyn. 2004; 229(3):591-599. [PubMed: 14991714]

Zhong J, Pevny L, Snider WD. "Runx"ing towards sensory differentiation. Neuron. 2006; 49(3):325327. [PubMed: 16446135]

Zhou Q, Choi G, Anderson DJ. The bHLH transcription factor Olig2 promotes oligodendrocyte differentiation in collaboration with Nkx2.2. Neuron. 2001; 31(5):791-807. [PubMed: 11567617]

Zirlinger M, Lo L, McMahon J, McMahon AP, Anderson DJ. Transient expression of the bHLH factor neurogenin-2 marks a subpopulation of neural crest cells biased for a sensory but not a neuronal fate. Proc Natl Acad Sci U S A. 2002; 99(12):8084-8089. [PubMed: 12060754] 


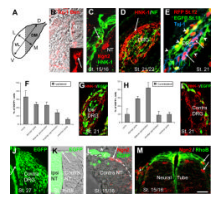

Figure 1.

Patterned assembly of the early DRG. (A) Schematic of the dorsal root ganglion (DRG) showing dorsal, ventral, medial, and lateral directions, and the dorsomedial and ventrolateral regions of the gangion. (B) DRG neurons (co-labeled with Tuj-1 and Ben, arrow) at St. 15/16. Inset shows the dashed box at higher magnification. (C) Ngn2 expression at St.15/16. (D) At St.21/22 the DRG consists of a neuronal core (Neurofilament; NF+) surrounded by undifferentiated neural crest cells (NCCs) (HNK-1+). (E) Early migrating NCCs (RFP+/ EGFP-; labeled at St.12/13) form a neuronal core (Tuj-1+, arrows) around which later migrating NCCs (EGFP+, labeled at St.17/18) (arrowheads) coalesce. Since electroporation only transfects $50-85 \%$ of targeted cells (Krull, 2004), numerous late-migrating NCCs are green (RFP-/EGFP+) rather than yellow (RFP+/EGFP+). (F,G) St. 21. Most ipsilaterally migrating NCCs colonize the DRG core. (H,I) Most contralaterally migrating NCCs colonize the DRG lateral perimeter. (J) By St.27 EGFP+ cells are present throughout the contralateral DRG, including dense colonization of the medial perimeter (arrow) (section thickness $=80 \mu \mathrm{m})$. $(\mathrm{K})$ Contralaterally-migrating NCCs delaminate near the dorsal midline (arrow). (L,M) Ngn2+ NCCs delaminate at lateral positions (arrows) as EGFP+ NCCs (asterisk in L) migrate contralaterally along the dorsal surface of the neural tube. (M) Both $\mathrm{Ngn} 2+$ premigratory (arrows) and migrating NCCs (arrowhead) are located at ventral positions relative to RhoB+ premigratory NCCs. Error bars in F, H represent standard deviation. Scale bar: $30 \mu \mathrm{m}$ in B,D,G,I,K; $10 \mu \mathrm{m}$ in B inset, C,L; $20 \mu \mathrm{m}$ in E; $50 \mu \mathrm{m}$ in J; 20 $\mu \mathrm{m}$ in M. D, dorsal; Dm, dermamyotome; DM, dorsomedial; DRG, dorsal root ganglion; Contra, contralateral; Ipsi, ipsilateral; L, lateral; M, medial; NT, neural tube; V, ventral; VL, ventrolateral. Magenta-green version available as Supplemental Figure 3. 

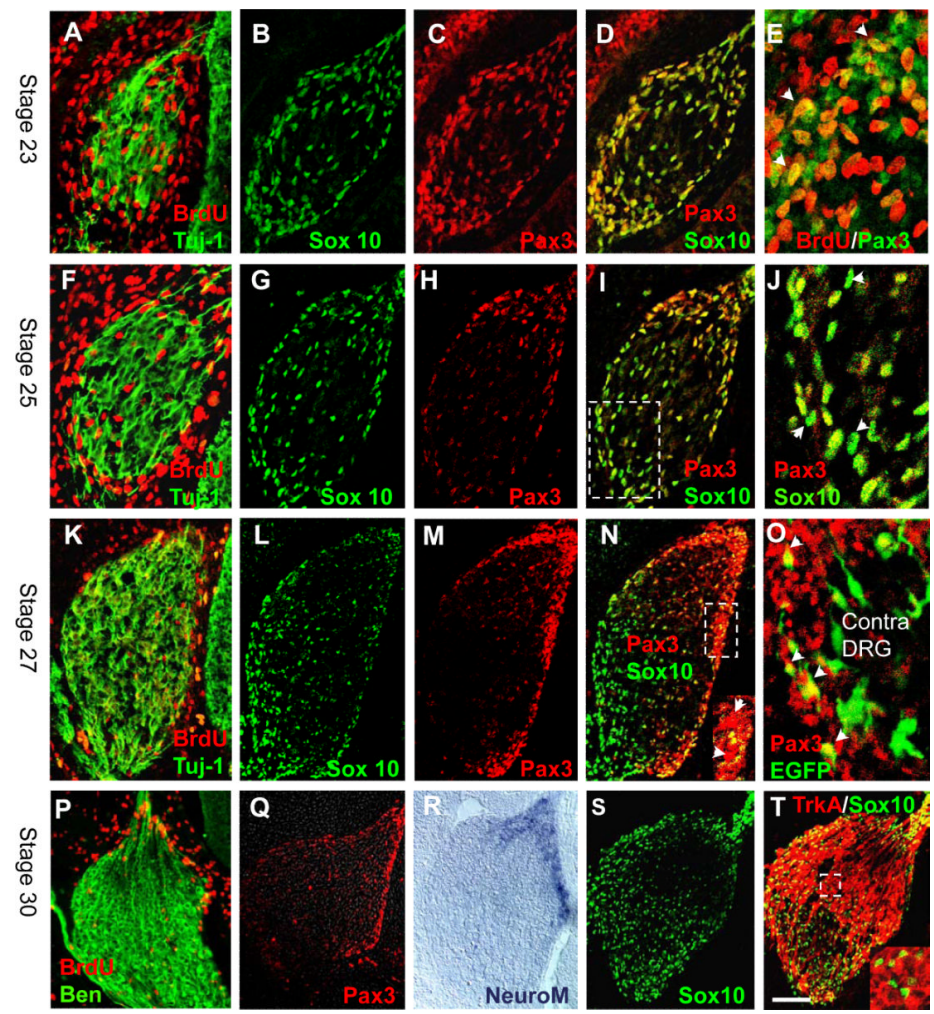

Figure 2.

Mitotic activity and dynamic progenitor expression in the DRG perimeter. (AE) E4/St.23. The dorsal root ganglion (DRG) comprises a neuronal core (Tuj-1+) surrounded by proliferating (BrdU+) Sox10+/Pax3+ progenitors. Arrowheads in E show co-localization of Pax3 and BrdU. (F-J) E4.5/St.25. (F) Dividing progenitors (BrdU+) surround the neuronal core (Tuj-1+). (G-J) Sox10 expression remains uniform throughout the perimeter, while Pax3 has shifted in the dorsomedial (DM) direction. (J) Dashed box in (I) at higher magnification. Arrowheads show Sox10+/Pax3- cells. (K-O) E5/St.27. (K) Mitotic activity is restricted to the medial and dorsolateral (DL) perimeter. (L) Abundant Sox10+ cells in the ventrolateral (VL) perimeter spread medially. $(\mathrm{M}, \mathrm{N})$ Pax3+ cells are abundant along the medial and DL perimeter. Arrowheads in inset $(\mathrm{N})$ show Pax3+/Sox 10- cells. (O) Arrowheads show contralateral Pax3+ cells in the medial DRG perimeter. (P-T) E6.5/St.30. $(\mathrm{P}-\mathrm{R})$ Mitotic activity (P), Pax3 expression (Q), and NeuroM expression (R) are limited to the DRG dorsal pole and DM perimeter. (R) In situ hybridization. (S) Except for the DM pole, Sox 10+ cells are populous throughout the DRG. (T) Juxtaposed Sox10+ cells and TrkA+ neurons. Inset shows the dashed box at higher magnification. Scale bar: $30 \mu \mathrm{m}$ in A$\mathrm{D}, \mathrm{F}-\mathrm{I} ; 10 \mu \mathrm{m}$ in E,J,N(inset), O,T(inset); $40 \mu \mathrm{m}$ in K-N; $50 \mu \mathrm{m}$ in P-T. Contra, contralateral; DRG, dorsal root ganglion. Magenta-green version available as Supplemental Figure 4. 

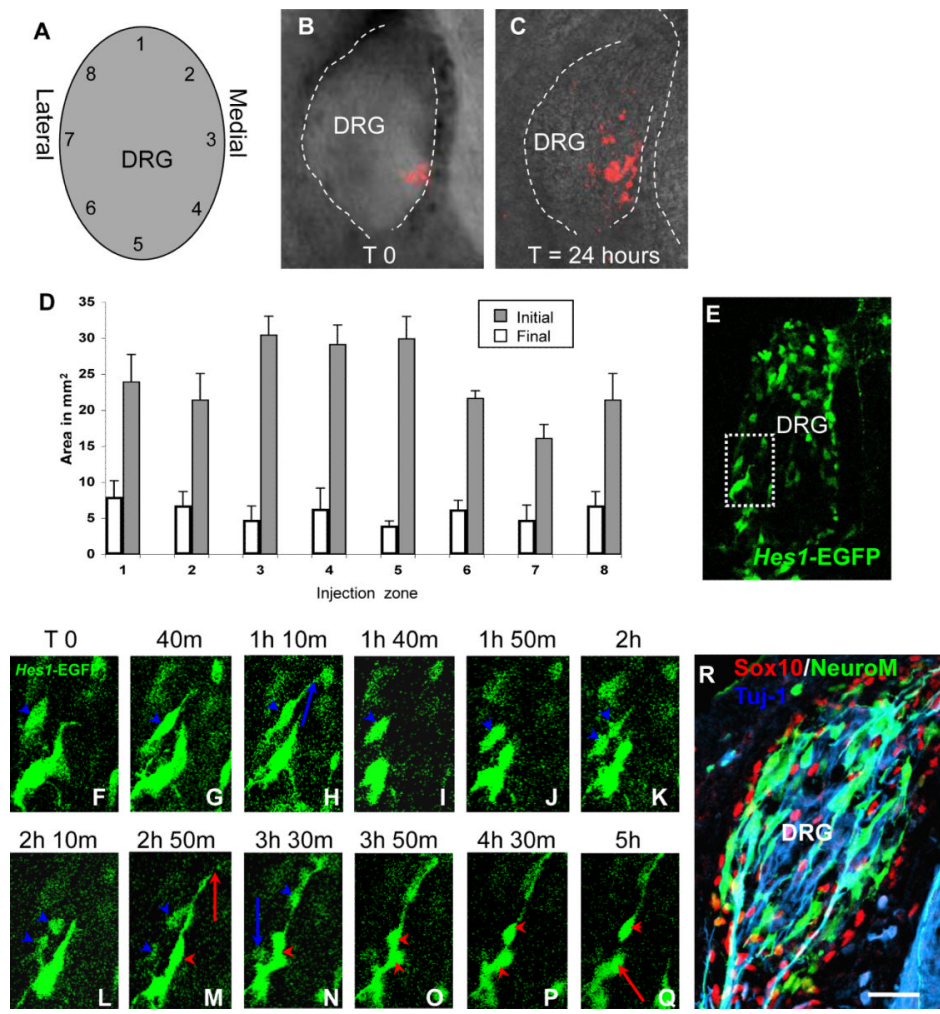

Figure 3.

Perimeter derived precursors migrate toward an internal zone of neuronal differentiation. (A-D) St.25. DiI injections into distinct regions of the dorsal root ganglion (DRG) perimeter. A) Schematic showing the geographic position of each zone injected. (B) Sample injection into medial zone 4 at $\mathrm{T}=0$ hours and (C) $\mathrm{T}=24$ hours. (D) Migration of DiI labeled cells and daughters. Graph shows the average size of the initial (white bars) vs. final (grey bars) size of the DiI labeled cell mass. Error bars represent standard deviation. (E-Q) Transverse slice preparation from a St.25 embryo showing EGFP expression via the Hesl reporter. (F-Q) Dashed box in E at higher magnification. Two EGFP+ cells within the lateral DRG perimeter (cell $1=$ blue arrowheads, cell $2=$ red arrowheads) extend filopodia in the dorsomedial (DM) direction where they make contact with a faint EGFP+ cell (arrows in H, $\mathrm{M})$. After this contact, both perimeter cells divide such that one DM and one ventrolateral (VL) cell is produced (blue arrowheads in $\mathrm{K}$; red arrowheads in O). Following these divisions, both medial daughter cells migrate inward (medial blue arrowhead in K-N; medial red arrowhead in O-Q), while the lateral daughter cells remain in the perimeter (blue arrow in N; red arrow in Q). (R) St.23. NeuroM reporter expression identifies a ring of neuronal differentiation interior to the Sox $10+$ perimeter and exterior to the Tuj-1+ neuronal core. Scale bar: $30 \mu \mathrm{m}$ in B,C; $30 \mu \mathrm{m}$ in E; $8 \mu \mathrm{m}$ in F-Q; $15 \mu \mathrm{m}$ in R. DRG, dorsal root ganglion; $\mathrm{h}$, hours; $\mathrm{m}$, minutes; $\mathrm{T}$, time. 

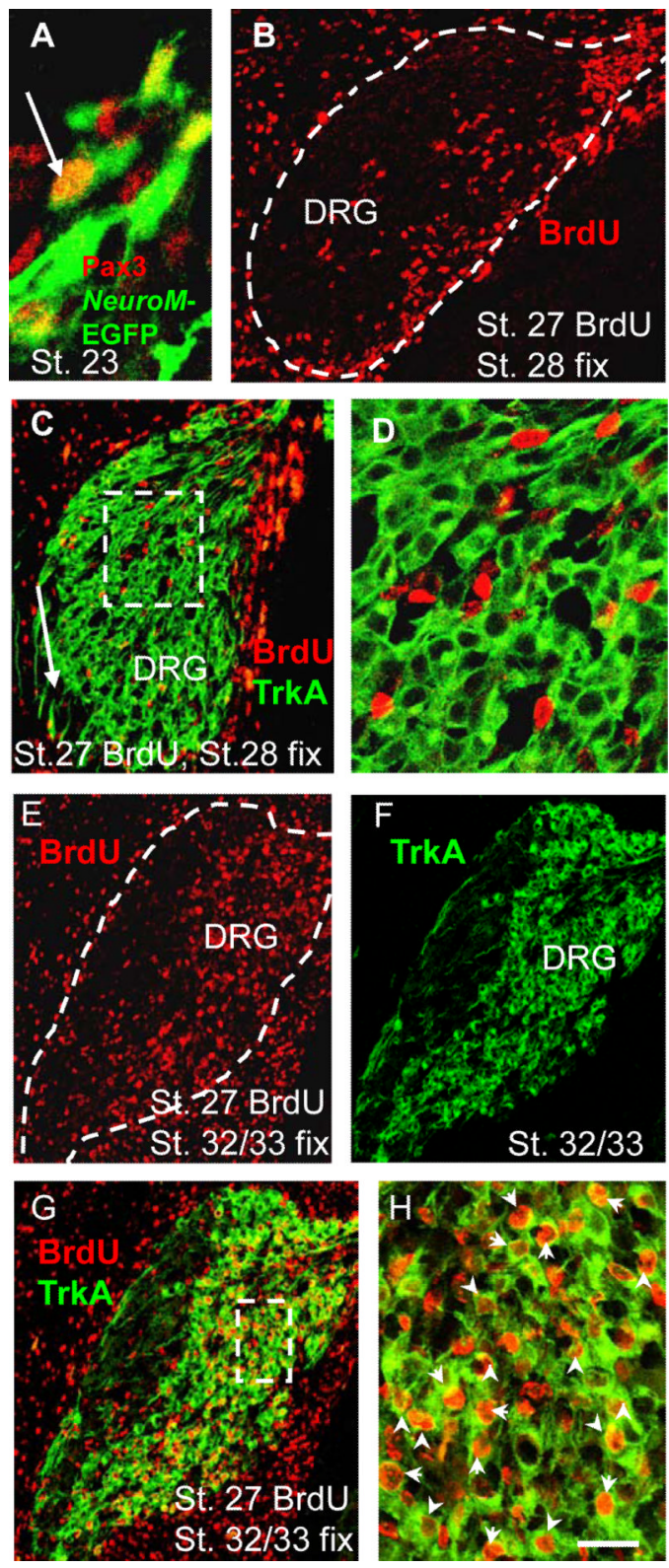

Figure 4.

Pax 3+ progenitors in the IOMZ give rise to late, TrkA+ neurons in the dorsomedial DRG. (A) Arrow indicates a Pax3+ cell expressing the NeuroM reporter. (B-D) Inner and Outer Marginal Zone (IOMZ) cells labeled by an 18-hour BrdU pulse at St.27 are confined to the dorsomedial (DM) 1/3 of the dorsal root ganglion (DRG). (C,D) Although TrkA+ neurons are dispersed throughout the DRG, except in rare sections that show the beginnings of DM localization (arrow), most BrdU+ cells are TrkA-. (D) Dashed box in C at higher magnification. (E-H) IOMZ cells labeled by a 72-hour BrdU pulse are restricted to the DM $2 / 3$ of the DRG and are primarily TrkA+ (arrowheads in $H)$. (G) overlay of E and F. $(H)$ Dashed box in $G$ at higher magnification. Scale bar: $8 \mu \mathrm{m}$ in $\mathrm{A} ; 40 \mu \mathrm{m}$ in B,C; $15 \mu \mathrm{m}$ in $\mathrm{D}, \mathrm{H} ; 50 \mu \mathrm{m}$ in E,F,G. DRG, dorsal root ganglion. Magenta-green version available as Supplemental Figure 5. 

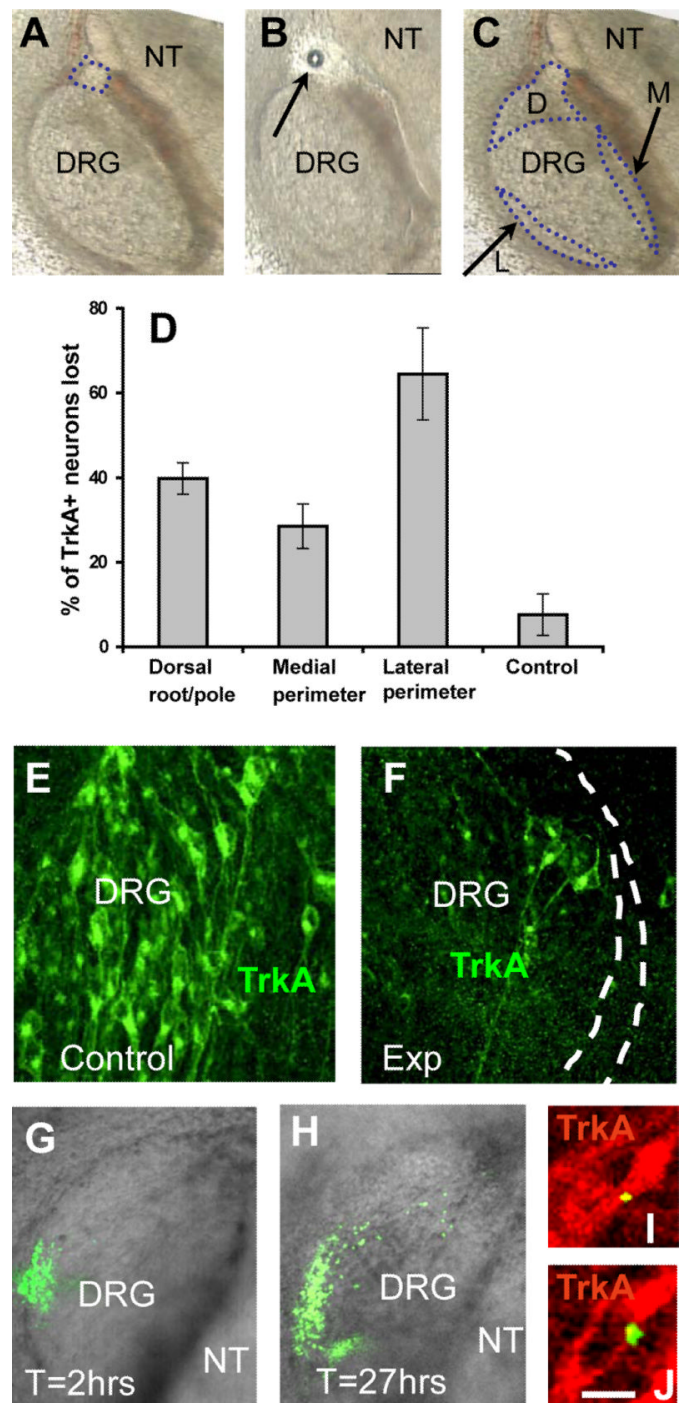

Figure 5.

Early TrkA neurons derive from progenitors dispersed throughout the DRG perimeter. (A,B) Sample ablation of the dorsal root. A) $200 \mu \mathrm{m}$ transverse slice explant prior to ablation. The dotted line shows the region selected for ablation. B) Post ablation image shows a hole (and bubble) in the slice, demonstrating the precision of the UV laser (arrow). (C) Schematic showing ablated regions of the dorsal root ganglion (DRG) perimeter. (D) Ablation of the DRG dorsal root/pole ( $\mathrm{n}=6$ slices), medial perimeter $(\mathrm{n}=6$ slices), and lateral perimeter $(\mathrm{n}$ $=8$ slices) differentially impact the generation of early TrkA+ neurons. Error bars show standard deviation. (D-F) Ablation of the lateral perimeter results in the greatest loss of early TrkA+ neurons. Dashed line in F shows the region ablated. (G-J) When progenitor cells in the ventrolateral perimeter are labeled with fluorescent micro-beads, they give rise to TrkA+ neurons in the DRG interior. Scale bar: $40 \mu \mathrm{m}$ in A-C,G,H; $20 \mu \mathrm{m}$ in E,F; $3 \mu \mathrm{m}$ in I,J. D, dorsal root/pole; DRG, dorsal root ganglion; Exp, experimental; L, lateral perimeter; M, medial perimeter; NT, neural tube. Magenta-green version available as Supplemental Figure 6. 

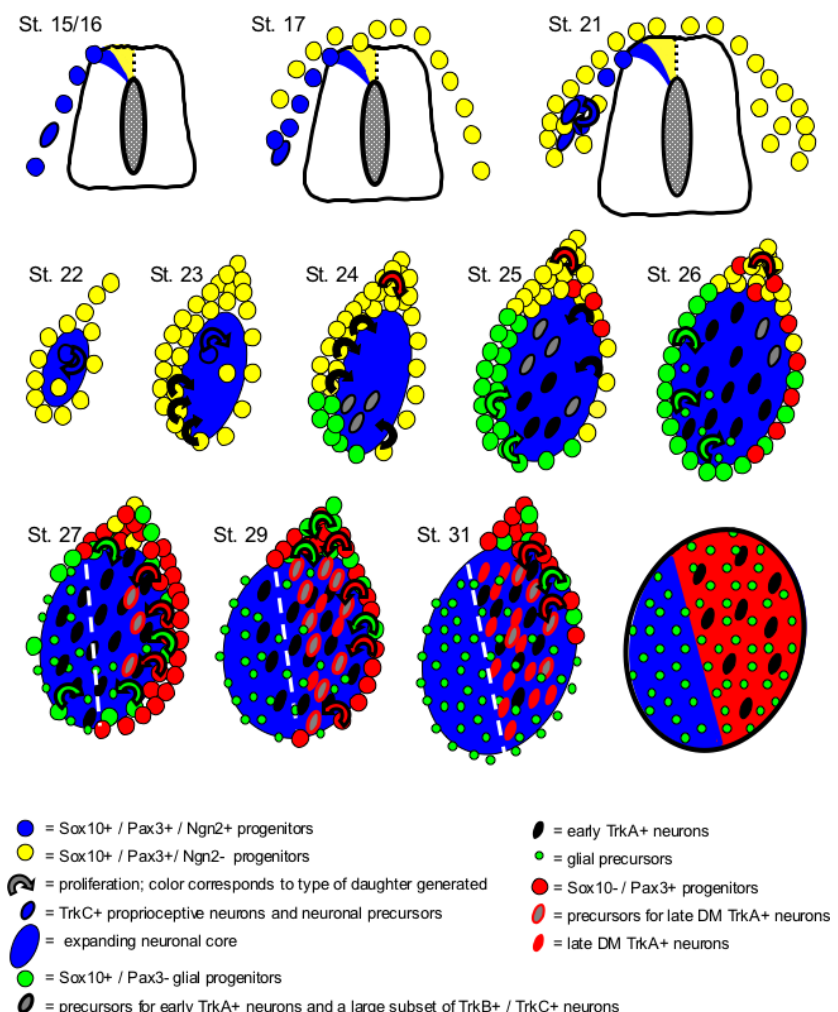

$\mathbf{O}=$ precursors for early TrkA+ neurons and a large subset of TrkB+ / TrkC+ neurons

Figure 6.

Proposed model for DRG development and the second wave of neurogenesis. Sox10+/ Pax3+/Ngn2+ NCCs (blue circles) give rise to the first neurons (blue ovals) born in the dorsal root ganglion (DRG). These neurons form a nucleus around which additional Ngn2+ NCCs, differentiating neurons (blue ovals), and later migrating Sox10+/Pax3+/Ngn2- NCCs (yellow circles) coalesce. Ngn2+ NCCs delaminate from lateral regions of the dorsal neural tube (blue shading) and migrate exclusively ipsilaterally. Ngn2- NCCs delaminate near the dorsal midline (yellow shading) and migrate either ipsilaterally or contralaterally. By St. 21-23 the DRG consists of a neuronal core (large blue oval) encapsulated by undifferentiated Ngn2- progenitors, the majority of which reside in lateral positions. During St.23-25 progenitors in the ventrolateral (VL) perimeter begin divisions that generate one lateral and one medial daughter (black circular arrows). Medial daughters transiently express Pax3, migrating inward as neuronal precursors (grey ovals with black outline) and give rise to early TrkA+ neurons (black ovals) and a subset of TrkB+ / TrkC+ neurons that are born throughout the DRG. Lateral daughters cease Pax3 expression and maintain Sox 10 (green circles), and begin generating glia (small green circles) at approximately St.25 (green arrows). Similar divisions and the loss of Pax3 expression continue in a dorsally progressing wave around the DRG perimeter, (yellow to green color shift). During this same time frame, Sox 10+/Pax3+ progenitors in the DRG dorsal root/pole proliferate (red arrow) and colonize the inner and outer marginal zone with robustly Pax3+ daughters (red circles). During St. 27-30 these new neuronal progenitors divide, giving rise to precursors that migrate into the dorsal medial (DM) 2/3 of the DRG (gray ovals with red outline) and begin expressing TrkA after St.28 (red ovals). During this same period the generation of glia continues, progressing around the perimeter in the dorsal direction in concert with diminishing Pax3 expression. Finally, TrkA+ neurons in VL positions either die, migrate into the DM DRG, or down regulate TrkA expression, with the most VL positioned TrkA+ neurons disappearing first. 
TABLE 1

Primary Antibodies Used

\begin{tabular}{|c|c|c|c|c|}
\hline Antibody name; Antigen & Immunogen & Host & Dilution & Source \\
\hline $\begin{array}{l}\text { Tuj-1 monoclonal; Neuronal class } \\
\text { III beta tubulin }\end{array}$ & $\begin{array}{l}\text { Rat peptide epitope } \\
\text { CEAQGPK }\end{array}$ & Mouse & $1: 1,000$ & Covance (Princeton, NJ), \#MMS-435P \\
\hline $\begin{array}{l}\text { BEN (SCI) monoclonal; neuronal } \\
\text { cell surface glycoprotein }\end{array}$ & $\begin{array}{l}\text { E16 chick bursal } \\
\text { epithelium }\end{array}$ & Mouse & $\begin{array}{l}\text { Supernatant } \\
\text { diluted in NGS } \\
\text { to } 2 \mu \mathrm{g} / \mathrm{ml}\end{array}$ & $\begin{array}{l}\text { Nicole Le Douarin and Olivier Pourquié, } \\
\text { University of Iowa Developmental } \\
\text { Studies Hybridoma Bank (DSHB) }\end{array}$ \\
\hline $\begin{array}{l}\text { HNK-1 monoclonal; glycoprotein } \\
\text { present on migrating NCCs and } \\
\text { NCC-derived neurons }\end{array}$ & $\begin{array}{l}\text { Human lymphoblastoid } \\
\text { cell line }\end{array}$ & Mouse & $\begin{array}{l}\text { Supernatant } \\
\text { diluted in NGS } \\
\text { to } 2 \mu \mathrm{g} / \mathrm{ml}\end{array}$ & $\begin{array}{l}\text { American Type Culture Collection } \\
\text { \#TIB-200 }\end{array}$ \\
\hline $\begin{array}{l}\text { Pax } 3 \text { monoclonal; transcription } \\
\text { factor involved in maintaining NCC } \\
\text { pluripotency }\end{array}$ & $\begin{array}{l}\text { Quail Pax3 amino acids } \\
\text { 298-481 }\end{array}$ & Mouse & $\begin{array}{l}\text { Supernatant } \\
\text { diluted in NGS } \\
\text { to } 2 \mu \mathrm{g} / \mathrm{ml}\end{array}$ & $\begin{array}{l}\text { Charles P. Ordahl, University of Iowa, } \\
\text { DSHB }\end{array}$ \\
\hline $\begin{array}{l}\text { RhoB ( } 56.4 \mathrm{H} 7) \text { monoclonal; GTP- } \\
\text { binding protein }\end{array}$ & $\begin{array}{l}\text { Chick RhoB amino } \\
\text { acids } 114-196\end{array}$ & Mouse & $\begin{array}{l}\text { Supernatant } \\
\text { diluted in NGS } \\
\text { to } 4 \mathrm{ug} / \mathrm{ml}\end{array}$ & $\begin{array}{l}\text { Thomas M. Jessell, University of Iowa, } \\
\text { DSHB }\end{array}$ \\
\hline $\begin{array}{l}\text { Sox } 10 \text { polyclonal; transcription } \\
\text { factor expressed by neural and glial } \\
\text { progenitor cells }\end{array}$ & $\begin{array}{l}\text { Rat Sox } 10 \text { amino acids } \\
181-233 \text { and } 308-400 \\
\text { (Stolt et al., 2003) }\end{array}$ & Guinea Pig & $1: 750$ & $\begin{array}{l}\text { M.Wegner, Universität Erlangen- } \\
\text { Nürnberg, Germany }\end{array}$ \\
\hline $\begin{array}{l}\text { BrdU monoclonal; thymidine } \\
\text { analog }\end{array}$ & $\begin{array}{l}\text { BrdU conjugated to } \\
\text { keyhole limpet } \\
\text { hemocyanin (KLH) } \\
\text { (Gratzner, 1982) }\end{array}$ & Rat & $1: 500$ & Oxford Biotechnology \#ОВT0030 \\
\hline $\begin{array}{l}\text { Ngn2 polyclonal; transcription } \\
\text { factor expressed by a subset of } \\
\text { NCCs }\end{array}$ & $\begin{array}{l}\text { Chick Ngn2 amino } \\
\text { acids 194-211 (KLH) }\end{array}$ & Guinea Pig & $1: 30,000$ & $\begin{array}{l}\text { Bennett Novitch, University of California, } \\
\text { Los Angeles }\end{array}$ \\
\hline $\begin{array}{l}\text { Neurofilament polyclonal; } 70 \mathrm{~K} \\
\text { neurofilament found in neurons and } \\
\text { erythrocytes }\end{array}$ & $\begin{array}{l}\text { Chicken spinal cord } \\
\text { (Granger and Lazarides, } \\
\text { 1983) }\end{array}$ & Rabbit & $1: 250$ & Bruce Granger, Montana State University \\
\hline $\begin{array}{l}\text { TrkA polyclonal; neuronal nerve } \\
\text { growth factor receptor }\end{array}$ & $\begin{array}{l}\text { Chick TrkA } \\
\text { extracellular domain } \\
\text { isolated from E8 DRG } \\
\text { (Lefcort et al., 1996; } \\
\text { Oakley et al., 1997) }\end{array}$ & Rabbit & $1: 750$ & $\begin{array}{l}\text { Frances Lefcort, Montana State } \\
\text { University; L.F. Reichardt, University of } \\
\text { California, S.F. }\end{array}$ \\
\hline
\end{tabular}

